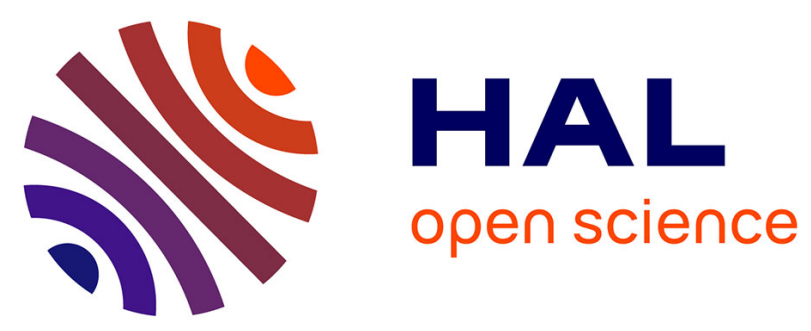

\title{
Do Labour Markets and Educational and Training Systems Matter for Innovation Outcomes? A multi-level analysis for the EU-27
}

Edward Lorenz

\section{- To cite this version:}

Edward Lorenz. Do Labour Markets and Educational and Training Systems Matter for Innovation Outcomes? A multi-level analysis for the EU-27. Science and public policy, 2011, 39 (9), pp.691-702. 10.3152/030234211X13070021633206 . halshs-00726797

\section{HAL Id: halshs-00726797 \\ https://shs.hal.science/halshs-00726797}

Submitted on 31 Aug 2012

HAL is a multi-disciplinary open access archive for the deposit and dissemination of scientific research documents, whether they are published or not. The documents may come from teaching and research institutions in France or abroad, or from public or private research centers.
L'archive ouverte pluridisciplinaire HAL, est destinée au dépôt et à la diffusion de documents scientifiques de niveau recherche, publiés ou non, émanant des établissements d'enseignement et de recherche français ou étrangers, des laboratoires publics ou privés. 


\title{
Do Labour Markets and Educational and Training Systems Matter for Innovation Outcomes? A multi-level analysis for the EU-27 ${ }^{1}$
}

\author{
Edward Lorenz \\ University of Nice - CNRS \\ Lorenz@gredeg.cnrs.fr
}

\section{Introduction}

Recent work on national systems of innovation has argued that there are systemic relations between national labour market and education and training systems, and the dynamics of knowledge creation and innovation at the enterprise level (Amable 2003; Hall and Soskice 2001; Lorenz and Lundvall 2006; Whitley 2006). Building on the insights of this research, Lorenz and Lundvall in a series of recent publications provide empirical evidence showing that in nations combining flexibility on the labour market with well-developed systems of unemployment protection establishments are more likely to organise work in ways that make use of employees' capacity for creative learning and problem solving (Lorenz and Lundvall, $2010,2011)^{2}$

The main objective of this paper is to extend this analysis by directly exploring the links between institutional context and the innovation performance of firms in the member nations of the EU-27. The empirical analysis focuses on the role of labour markets and education and training systems, and it makes use of data available on Eurostat's electronic data base in order to develop measures of labour market flexibility, the provision of unemployment protection including the use of active labour market policies, and the development of systems of further education and training for the EU-27. Drawing on enterprise-level data from the 2007 Innobarometer Survey, a measure of enterprise innovative performance is developed, and this is used in a multi-level logistic model in order to examine simultaneously the impact of enterprise-level and national-level variables on the likelihood of an enterprise innovating.

\footnotetext{
1 A preliminary version of this paper was presented at the Schumpeter Conference 2010 held in Aalborg, Denmark and at the CICALICS Workshop held in Hangzhou, China at Zeijiang University in August of 2010. I would like to thank the participants for their remarks and in particular Anthony Arundel for detailed comments. Comments provided by two anonymous referees for the Special Number of Science and Public Policy proved especially valuable for revising the preliminary version of the paper. I would also like to express my gratitude to Keith Sequeira of Unit 1 - Innovation Policy Development, DG Enterprise and Industry, European Commission, for providing me with access to the micro data from the 2007 Innobarometer Survey.

${ }^{2}$ Also see Holm et al. (2010) for the links between work organization and systems of labour market regulation.
} 
The paper begins in Section 2 with a consideration of the impact of labour market flexibility on innovation performance and it critically examines work from a varieties of capitalism perspective that has drawn a connection between flexibility in national labour markets and differences in the innovation style of enterprises. This leads in to a presentation of the basic hypothesis of the paper that innovative performance is supported by national systems of 'flexicurity' which combine flexibility on the labour market with the generous provision of unemployment protection including the use of active labour market policies, and broad-based systems of life-long learning. Sections 3 and 4 develop empirical indicators and present the results of econometric analysis. Section 3 uses factor analysis in order to characterise the labour market and education and training systems of the EU-27. Section 4 presents the results of the multi-level logistic analysis of innovation performance. Section 5 concludes and briefly raises the policy implications of the results.

\section{Labour market mobility, skills and innovation performance}

The contribution of labour market mobility to the innovative performance of enterprises has often been raised in the literature focusing on innovation at the regional and national levels. Labour mobility, for example has often been identified as a factor in the innovative performance of regionally clustered high-technology firms, such as the cluster of firms in Silicon Valley (Saxenian, 1996; Angel, 1991; Almeida and Kogut (1999); Carnoy et al. 1997, Rogers and Larsen 1984). More generally, work in economic geography has identified labour mobility as an important mechanism supporting knowledge transfer and innovation within regions (Boschma et al., 2009; Breschi and Lissoni, 2001; Camagni, 1991; Gertler, 2003)

Within a national systems framework, probably the most systematic treatment of the way labour mobility impacts on enterprise innovative performance can be found in the varieties of capitalism (VoC) literature (Hall and Soskice, 2001). This literature draws a distinction between radical innovations associated with the introduction of new product lines or major changes in production processes, and more incremental innovations that further develop existing products and technologies. The basic argument developed in the VoC approach is that in national systems where labour is highly mobile due to the lack of restrictions on hiring and firing, and where the education and training system favours investments in general over industry or company-specific skills, enterprises will have a comparative advantage in the development of more radical innovations. The explanation for this is that the lack of 
restrictions on hiring and firing combined with ample supplies of mobile generally trained labour makes it easier for management to rapidly reconfigure the enterprise's knowledge base in order to introduce new product lines (Hall and Soskice, 2001, pp. 40-41).

There are some important weaknesses with this argument, though, that might help explain why recent attempts to empirically test the VoC hypothesis have found little support for the basic proposition regarding how national institutional arrangements favour different types of innovation. ${ }^{3}$ First, fluid labour markets might just as easily contribute to the innovative performance of 'follower' firms that confronted by radical changes in technology seek to reconfigure their knowledge base in order to compete by imitating or introducing minor modifications to the new products initially developed by other organisations. Fluid labour markets, then, might prove an advantage for rapid catch-up in nations that are good at imitating the innovations developed in other nations.

Secondly, the VoC approach appears to be premised on the idea that the competencydestroying nature of radical innovations means that firms operating in the newly emerging industries that these innovations give rise to will be unconcerned by the loss of the industry or firm-specific skills of their existing employees (Hall and Soskice, 2001, p. 40). This premise, however, finds little support in the case-study literature. The history of the production of integrated circuits in Silicon Valley provides a case in point. Transistors which substituted for, and were competence destroying in relation to, vacuum tubes were invented in 1948 by Bell Lab scientists, including William Shockley who later founded the first semi-conductor firm in Silicon Valley. Transistors substituted for many applications of vacuum tubes and although they were competence-destroying most of the early producers of transistors were electronic firms that produced vacuum tubes, including GE, RCA, Raytheon, Sylvania, Motorola and Texas Instruments. (Klepper, 2007).

Robert Noyce, one of the traitorous eight that founded Fairchild, invented integrated circuits containing many transistors on a substrate of semi-conductor material in 1958. Most early production of integrated circuits used a substrate of germanium. Noyce and scientists at Fairchild developed the planar process using an entire silicon substrate which eventually became the industry standard (Klepper, 2007, p. 5). Subsequent improvements in integrated

\footnotetext{
${ }^{3}$ For empirical tests based on the use patent citation data, see Taylor (2004) and Akkermans et al. (2009).
} 
circuits involved vastly increasing the number of transistors on a single chip, from as few as 10 in 1950s, to hundreds in the 1960s (medium-scale integration) and tens of thousands in the 1970s (large-scale integration).

Following Fairchild's invention of the integrated circuit, the number of Silicon chip producers in Silicon Valley rapidly increased. According to the genealogy presented in Klepper (2007), many of these were spin-offs from existing firms and of the 23 spin-offs generated by 1969 eight came out of Fairchild. Further entries, many of them spin-offs of existing enterprises, occurred during the early 1970s, and by 1975 the dominance of Silicon Valley in the production of integrated circuit was established, with Silicon Valley firms accounting for 38 percent of the market.

The lineage of Silicon Valley producers, with the majority entering the market as spin-offs from established firms in the region, points to the importance of industry-specific knowledge for success in what is generally accepted to be a radically innovative sector. The role that the clustering of firms into localised networks played in helping Silicon Valley firms to cope with the problems that labour turnover posed for preserving essential skills also speaks to importance of both industry and firm specific knowledge. This is recognised by Gordon Moore, co-founder of Intel, who in a discussion paper analysing the conditions for Silicon Valley's success clearly points to the importance of industry and firm-specific knowledge:

\begin{abstract}
"Aligning the goals and incentives of the firm with those of the talented individuals whose efforts build a successful firm takes on greater importance in highly technical, skill-intensive firms. The goals of the firm must be clear, and the payoffs for employees certain. The scarcity of these trained scientists and engineers makes them difficult to replace. Moreover, especially in high technology firms, employees quickly develop project- and firm-specific knowledge. When the opportunity to apply that knowledge (outside the current firm) is great - i.e. in most high technology businesses - the costs of mismanaging personnel become greater.” (Moore and Davis, 2001, p. 7)
\end{abstract}

\title{
2.1 Flexicurity, cognitive distance and innovative performance
}

An alternative understanding of the contribution of labour mobility to innovative capacity focuses on the cognitive dimensions of the innovation process and on the way diversity in knowledge supports the creation of novelty. Nooteboom $(1999,2000)$, in particular, has argued that an enterprise's capacity for generating novelty depends on its ability to access 
outside sources of complementary knowledge that display an appropriate cognitive distance in relation to existing internal knowledge. If new knowledge from outside is the same as the knowledge held by the firm's existing members, there is a risk of myopia resulting in technological inertia. On the other hand, if the cognitive distance between the firm's existing knowledge base and the external sources of new knowledge is too great, there is a risk of limited comprehensibility. As Nooteboom (2000, p. 70) observes, an optimal cognitive distance is sufficiently small to permit comprehension but sufficiently large to yield nonredundant novel knowledge.

The cognitive distance perspective is consistent with the observation and that the geographical clustering of firms operating in the same technological field may enhance their innovative performance. The concentration of firms in a region facilitates firms' access to new knowledge with appropriate cognitive distance through the inter-firm mobility of employees who have knowledge that is partially overlapping, and hence comprehensible, due to their experience of working in the same technological field, and yet diverse enough to generate novelty due to careers paths which span different firms or organisations.

From this perspective, labour market mobility within industry clusters contributes to innovative performance not so much because they make possible a thoroughgoing reconfiguration of the innovative firm's knowledge base, but because they contribute to generating appropriate levels of cognitive distance while preserving access to essential industry-specific skills. While the novel knowledge which labour mobility may yield will be an important factor in the ability of firms to generate major innovations that transform existing markets, it may also play a role in their capacity to generate relatively minor innovations which nonetheless require creative thinking and new ideas.

This understanding the sources of novelty is consistent with the observation of Lundvall and Lam (2006) that labour market mobility is a two-edged sword for the innovative firm. Highly creative firms draw their capability from the industry-specific know-how and problem solving skills that are embodied in individual experts. While codified formal professional knowledge will play a role, the industry-specific problem solving capabilities of the expert may have more to do with his or her diverse experience and the tacit knowledge generated through interaction, trialand-error and experimentation in a variety of company settings. Because these industry-specific tacit skills cannot be easily codified, the creative firm faces a problem of reproducing what has 
been learnt into an organizational memory and is highly vulnerable when it comes to individuals leaving the organisation.

These problems of accumulating and transferring experience-based tacit knowledge take a different form when firms are organised into localised networks and industry clusters as in Silicon Valley. Mobility across organisational borders within industrial clusters contribute to professional and social relationships which provide the 'social capital' and 'information signals' needed to ensure the efficient accumulation and transfer of tacit knowledge in an inter-firm career framework (Saxenian, 1996).

Elsewhere, in publications co-authored with Lundvall and others (Lorenz and Lundvall, 2010, 2011; Holms, et al. 2010) the argument is made that the localised networks and professional and social relationships that contribute to the efficient accumulation and transfer of tacit knowledge are more likely to develop in institutional settings with well developed systems of unemployment protection in association with active labour market policies and the provision of life-long learning opportunities. Such systems of 'flexicurity' may serve these ends for various reasons. Firstly, in terms of incentives, the security such systems provide through income maintenance and support programmes for moving the unemployed into employment can encourage individuals to commit themselves to what would otherwise be perceived as unacceptably risky forms of employment and career paths. Second, well-developed and diversified systems of life-long-learning support not only formal training for the updating of scientific and the technical skills, but also informal forms of learning, including on-the-job training, that contribute to the acquisition of the tacit and experience-based knowledge that are crucial to the innovative activities of firms.

In what follows I provide an empirical test of the links between national systems of flexicurity and enterprise innovative performance by undertaking a multilevel logistic analysis that simultaneously explores the way firm-level characteristics and the national labour market context impact on a measure of enterprise innovation performance. Section 3 begins with a characterisation of the labour market systems of the member nations of the EU-27. 


\section{Characterising national labour market systems}

In order to characterise national labour market systems for the EU-27, a factor analysis is conducted on the basis of 5 aggregate indicators available on the website of Eurostat (see Table 1). Differences in the development of systems of life-long learning across EU member nations (LLL) are measured on the basis of the annual responses to the European Union Labour Force Survey. LLL is defined as the percent of the population, both active and inactive, between the ages of 24 and 65 that received education or training in the four weeks preceding the survey in 2007. LLL is broadly defined to include formal, non-formal and informal forms of learning. Formal life-long learning is defined as that provided by the degree conferring institutions of the formal educational system. Non-formal education and training refers to all forms of taught learning that occur outside the formal degree-conferring educational system. Informal learning refers to self-taught learning including the use of printed materials and on-line computer based learning. ${ }^{4}$ This broad measure of learning serves to capture the diverse types of knowledge that may contribute to innovative performance. Thus formal forms of lifelong learning can contribute to the updating of the formal scientific and technical knowledge required to keep abreast rapid changes in technology. Non-formal and informal learning typically contribute to the acquisition of more applied or experiencebased knowledge, including knowledge that may have little apparent relation to work-related activities. Further, by including in the measure of life-long learning the further education and training received by inactive persons, it is possible to takes into account that the knowledge gained during periods of inactivity may prove of value to the innovation-related activities of persons who have recently entered the labour market.

In order to capture the acquisition of more firm-specific and work-related-skills, two measures are used. The first, CVTC, which is based on the 2005 Continuing Vocational Training Survey, provides a measure of the acquisition of codified or formal knowledge. It is defined as the percentage of employees in all enterprises receiving continuing vocational training courses, either on or off the premises of the enterprise. The second, OJT, also is based on the results of the 2005 Continuing Vocational Training Survey, provides a measure of the

\footnotetext{
${ }^{4}$ For the definition of lifelong learning, see the Eurostat Quality Report: http://circa.europa.eu/irc/dsis/employment/info/data/eu_lfs/LFS_MAIN/Adhoc_modules/2003/ExplanatoryNotes /Final_Report_Ahm2003_EN.pdf
} 
acquisition of more tacit and experience-based knowledge. It is defined as the percentage of all enterprises that provide their employees with on-the-job training. ${ }^{5}$

Table 1

Country-level variables for Factor Analysis

\begin{tabular}{|c|c|c|c|c|c|}
\hline & FLEX & LLL & CVTC & OJT & LMP \\
\hline AT & 4.6 & 12.8 & 33 & 32 & 25537 \\
BE & 3.7 & 7.2 & 40 & 41 & 26532 \\
BG & 5.2 & 1.3 & 15 & 17 & 473 \\
CY & 5.4 & 8.4 & 30 & 19 & 6152 \\
CZ & 2.5 & 5.7 & 59 & 42 & 1102 \\
DE & 4.2 & 7.8 & 30 & 48 & 12710 \\
DK & 8 & 29.2 & 35 & 30 & 59193 \\
EE & 4.6 & 7 & 24 & 31 & 433 \\
ES & 7.3 & 10.4 & 33 & 26 & 10666 \\
FI & 9.1 & 23.4 & 39 & 35 & 19774 \\
FR & 6.3 & 7.5 & 46 & 29 & 15302 \\
GR & 2.6 & 2.1 & 14 & 6 & 2559 \\
HU & 3.1 & 3.6 & 16 & 18 & 1562 \\
IE & 5.1 & 7.6 & 49 & 43 & 24779 \\
IT & 3.7 & 6.2 & 29 & 11 & 10708 \\
LT & 4.7 & 5.3 & 15 & 18 & 810 \\
LU & 2.3 & 7 & 49 & 44 & 34370 \\
LV & 6.5 & 7.1 & 15 & 9 & 971 \\
MT & 3.3 & 6 & 32 & 31 & 2151 \\
NL & $5.1 *$ & 16.6 & 34 & 31 & 39826 \\
PL & 4.8 & 5.1 & 21 & 17 & 1244 \\
PT & 3.5 & 4.4 & 28 & 22 & 6130 \\
RO & 3.1 & 1.3 & 17 & 19 & 506 \\
SE & 8.9 & 18.6 & 46 & 34 & 19544 \\
SI & 4.4 & 14.8 & 50 & 28 & 2850 \\
SK & 2.6 & 3.9 & 38 & 32 & 604 \\
UK & 4.2 & 20 & 33 & 75 & 2710 \\
\hline
\end{tabular}

Source: Eurostat's electronic database.

* Imputed value. See ft nt. 6 below.

\footnotetext{
${ }^{5}$ Figures on the percentage of all enterprises providing on-the-job training are used rather than the percentage of employees involved in such training due to the fact that values for the latter series are missing for both the UK and Ireland. To qualify as continuous vocational training, the EU CVT survey manual sets three criteria: training must be planned in advance, it must serve the goal of learning and it must be partly financed by the enterprise; See 'The 3rd Continuing Vocational Training Survey (CVTS3): European Union Manual. (http://circa.europa.eu/Public/irc/dsis/edtcs/library?l=/public/continuing_vocational/master_finalpdf/_EN_1.0_\& $\mathrm{a}=\mathrm{d})$
} 
Differences in the fluidity of national labour markets fluid (FLEX) are captured with an indicator of short-term labour market flexibility based on the quarterly returns of the European Union Labour Force Survey. FLEX is defined as the share of persons aged 15 and over whose job started within the last three months and the figures presented in Table 2 are for the $2^{\text {nd }}$ quarter of 2007. FLEX is a general measure of labour market flexibility that includes both the job-to-job mobility of persons who have changed their employer over the reference period and the mobility of inactive persons into active employment. ${ }^{6}$ FLEX thus provides a means of capturing the way innovative firms may benefit not only from knowledge flows linked resulting from job-to-job mobility, but also from new knowledge acquired through hiring persons who were recently inactive.

In order to capture differences in the level of protection that unemployed persons benefit from, national expenditures on active and passive labour market policies (LMP) are taken from Eurostat's Labour Market Policy database. Active and passive expenditures are defined as those targeted at one of the following: the unemployed, the employed at risk of becoming unemployed and inactive persons who would like to enter the labour market but are disadvantaged in some way. Active measures include expenditures on training, job rotation and job sharing, employment incentives, direct job creation and start-up incentives. Passive measures include expenditures on out of work income maintenance and early retirement. In order to control for differences in the unemployment rate on national expenditures, the figures reported in Table 2 are total active and passive expenditures per registered unemployed person.

Factor analysis using the principal components factor method resulted in two factors with eigenvalues greater than 1 . These two factors were retained for oblique factor rotation in order to improve interpretability. Table 2 below reports the resulting factor loadings or correlations

\footnotetext{
${ }^{6}$ The figures are taken from, Romans, F. Data in Focus, 'Population and Social Conditions', 21/2007, Eurostat. Quarterly data for the Netherlands is reported as unreliable by Eurostat either due to the small sample size or due to the large non-response rate. The reported figure of 1.7 percent for the Netherlands, the lowest for the EU-27, does appear to be unrealistically low when compared with figures for annual job-to-job mobility based on the European Union Statistics on Income and Living Conditions (EU-SILK) survey which covered 21 EU nations in 2005. EU-SILK results showed annual job-to-job mobility in the Netherland in 2005 as being only slightly below the EU-21 average of 8.8 percent. Because of the unreliability of the data for the Netherlands, I have treated it as missing and have imputed the value using STATA's impute command. The imputed value of 5.1 percent for the Netherlands is slightly above the unweighted average for the EU-27 of 4.8 percent. For an overview of the EU-SILK based results, see Job Mobility in the European Union: optimizing its social and economic benefits, Danish Technical Institute, April 2008.
} 
between the two factors and the five original variables as well as the uniqueness for each variable. $^{7}$

Table 2

Rotated factor loadings and unique variances

\begin{tabular}{|l|l|l|l|}
\hline variable & Factor 1 & Factor 2 & Uniqueness \\
\hline FLEX & $\mathbf{. 9 3 4}$ & -.0235 & .167 \\
\hline LLL & $\mathbf{. 8 2 9}$ & .291 & .125 \\
\hline OJT & -.048 & $\mathbf{. 9 0 0}$ & .207 \\
\hline CVTC & .064 & $\mathbf{. 8 5 1}$ & .248 \\
\hline LMP & $\mathbf{. 6 5 2}$ & .325 & .379 \\
\hline
\end{tabular}

The first factor, which accounts for approximately 44 percent of the shared variance, is positively correlated with the measures of labour market flexibility, life-long-learning and expenditures on active and passive labour market policies per registered unemployed. This component can be interpreted as an indicator of flexicurity. It indicates that EU member nations can be scored on a scale measuring the extent to which they have developed institutional set-up combing what are often described as the three core components of flexicurity systems: generous unemployment protection including expenditures on active labour market policies, high levels of labour market flexibility, and well developed systems of lifelong learning. ${ }^{8}$ Such arrangements arguably create an environment that is supportive of strategies of continuous knowledge exploration due to the way they combine porous organisational boundaries that permit the continuous insertion of new knowledge and ideas from outside the firm, and social protection that serves to preserve industry-specific skills.

The second factor, which accounts for about 40 percent of the shared variance, is positively correlated with the two measures of continuous vocational training: the provision of formal training courses, either by the employer or by a third party, and the provision of on-the-job training. This factor, simply referred to as continuing vocational training, shows that EU member nations can be scored along a scale measuring the importance of their investments in further vocational training.

\footnotetext{
${ }^{7}$ The two factors are weakly correlated with a correlation coefficient equal to 0.214.

${ }^{8}$ See, for example, Bredgaard, et al. (2005) and Masden (2003).
} 
Figure 1 below shows graphically the position of the 27 member nations with respect to the two new latent variables or factors. The horizontal axes shows the scores or values of the nations on the flexicurity scale, with nations situated farther to the right scoring higher on this scale. The vertical axis shows the values of the nations on the continuous vocational training scale, with those situated higher on the axis scoring higher on this scale.

Figure 1

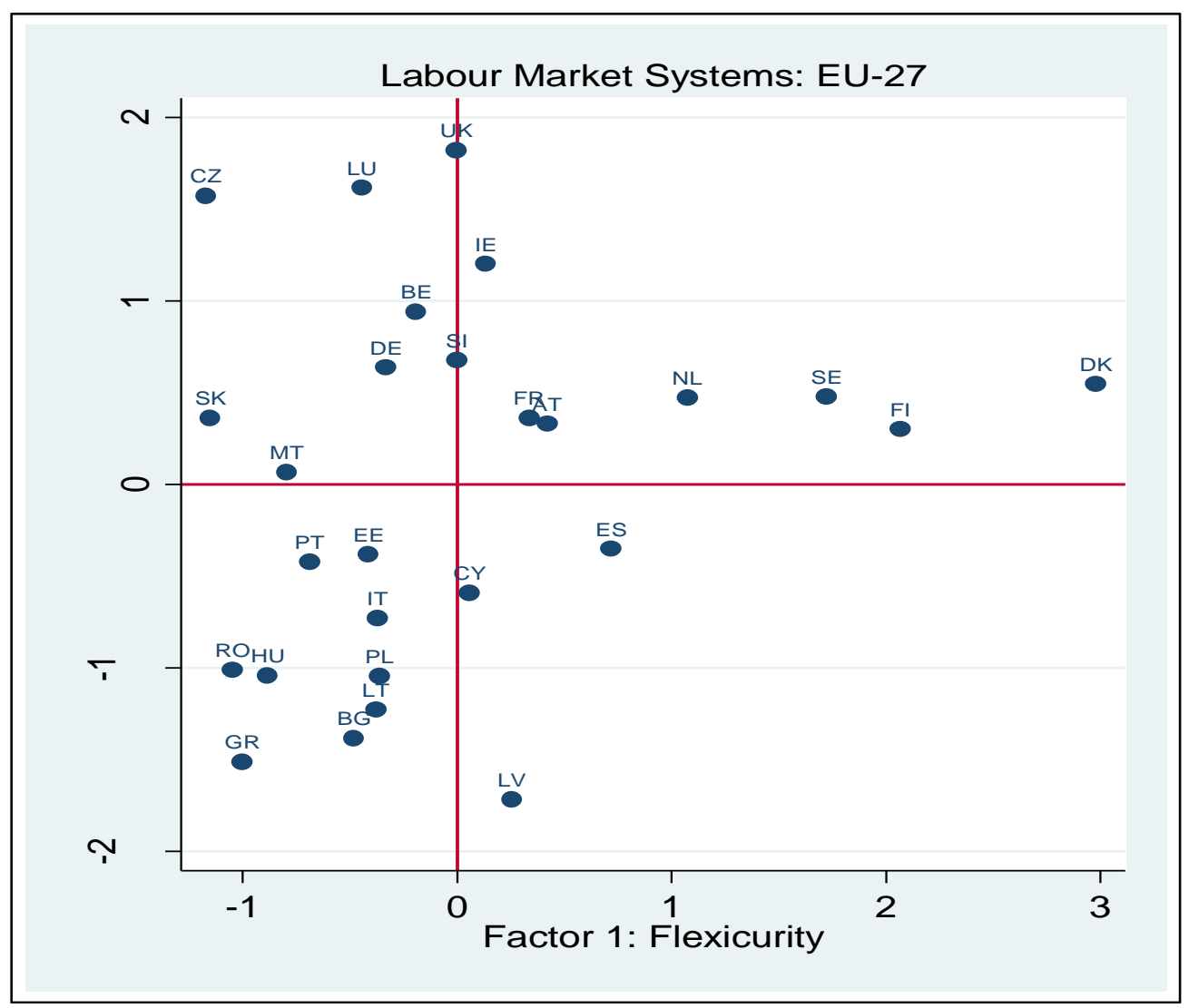

The figure shows, as might be expected, that the Scandinavian countries and the Netherlands score relatively high on the flexicurity scale. The continental nations, as well as the UK and Ireland, have scores grouped around the average, while most of the southern and new member nations have below-average scores. The countries with the lowest scores on the flexicurity scale are the Czech Republic, Romania, Slovakia and Greece. Amongst the new member countries the only nations with above average scores are Latvia and Cyprus. In the case of Latvia this reflects this country's relatively high levels of reported labour market flexibility, which balance out relatively low levels of involvement in life-long learning and extremely low levels of expenditure on labour market policies in comparison to the EU average of 
slightly over 12,000 euro per registered unemployed. ${ }^{9}$ Amongst the southern nations, Spain stands out for its relatively high score on the flexibility scale. This reflects its high reported level of labour market flexibility that is only exceeded by the levels reported in the three Scandinavian nations. ${ }^{10}$

With respect to the continuing vocational training scale, all the more developed EU member nations have scores that are above the EU-27 average, while the majority of the southern and new member nations have scores that are below the average. Amongst the new member nations the Czech Republic stands out for its relatively high levels of employee participation in both training courses and enterprise provision of on-the-job-training. Amongst the more developed EU nations the UK stands out as an outlier on this scale due to its very high reported level of enterprise provision of on-the-job training. ${ }^{11}$

\section{A multilevel analysis of innovation performance}

In this section I use multi-level logistic modeling to estimate the way the characteristics of enterprises and features of the national institutional context impact on the likelihood of an enterprise innovating in the sense of demonstrating an in-house capacity for developing new products or services. In multi-level analysis data is hierarchically structured. This means that units at one level are clustered within units at the next higher level and multi-level modeling allows one to model processes at multiple levels of the population hierarchy. The main reason for doing this in the context of this paper is to provide estimates of the impact of macro or national levels context conditions on micro or enterprise-level outcomes. In particular, by using the factor scores of the 27 member nations on the two underlying factors developed in Section 2 above, multi-level analysis provides a mean for the impact of national differences in

\footnotetext{
${ }^{9}$ For a discussion of the relatively high levels of labour market flexibility prevailing in the Baltic states despite levels of legislative employment protection that are at average levels for the EU, see Eamets and Massu (2005). ${ }^{10}$ Although the figures for Spain may appear high in lieu of this nation's reputation for relatively inflexible labour markets, they are consistent with the figures on annual job-to-job mobility for Spain based on EU-SILK (2005) which finds levels of mobility in Spain well above the European average and ranks Spain fourth highest amongst the 21 EU nations covered. See Job Mobility in the European Union: optimizing its social and economic benefits, Danish Technical Institute, April 2008, p. 21.

${ }^{11}$ There are no reasons to believe the reported figure of $75 \%$ of enterprises providing on-the-job training is unreliable. For a detailed description of the methodology including the quality procedures used for the UK Survey carried out under the auspices of the Department of Innovation, Universities and Skills, see Dent and Wiseman (2008).
} 
the development of systems of flexicurity and in the provision of continuing vocational training on the likelihood of an enterprise innovating. ${ }^{12}$

The econometric analysis of innovation performance operates at two levels, with enterprises at level-1 being clustered within nations at level-2. The variables characterising enterprises at level-1 are derived from the individual responses to the Innobarometer Survey carried out in the EU-27 and in Norway and Switzerland in October 2007 on behalf of the DG Enterprise and Industry of the European Commission. ${ }^{13}$ The analysis here concerns only the EU-27. The Innobarometer survey provides estimates of the percentage of enterprises that have introduced new or significantly improved products or services over the period 2005-2007. The target population for the survey was enterprises employing 20 or more persons in manufacturing and services. ${ }^{14}$ The survey used a random stratified sample with stratification according to size category and sector. Larger enterprises were oversampled in order to get enough cases for meaningful results. The target number of main interviews was 200 in each country surveyed, except Malta, Cyprus and Luxembourg where the target number of interviews was 70 . This resulted in a sample size for the EU-27 of 5036 observations. ${ }^{15}$

The measure of innovation performance is a binary variable with innovative enterprises being defined as those that have developed entirely new or significantly improved products in-house and that carryout R\&D in-house. This measure of innovativeness excludes both firms that have modified or customised products that were originally developed by other organisations and firms that have simply sold on products developed by other organisations. It also excludes firms that innovate on the basis of $R \& D$ that is contracted out to other organisations or that have innovated without undertaking any expenditures on $R \& D$. These enterprises constitute

\footnotetext{
${ }^{12}$ Another reason for using multi-level analysis is that the failure to take into account the hierarchically structured nature of the data may lead to technical problems, with standard errors of the regression coefficients being underestimated. See Rasbash, et al. (2005, pp. 6-12) and Goldstein (2003).

${ }^{13}$ Access to the micro data from the 2007 Innobarometer Survey was kindly provided by Keith Sequeira of Unit 1 - Innovation Policy Development, DG Enterprise and Industry, European Commission,

${ }^{14}$ The survey includes a very small percent of firms in agriculture and fishing. The person interviewed in each company was a top-level executive responsible for strategic decision-making (typically General Manager, Financial Director, or significant owner). For the survey methodology, see Innobarometer 2007 Analytical Report, DG Enterprise and Industry, European Commission, 2008, pp. 102-104.

${ }^{15}$ Similar measures of innovativeness could have been derived from the CIS-4 survey and while the use of CIS data would in principle allow for greater precision in statistical estimates due to the larger size of the national samples, its use for multi-level analysis was precluded due to the considerable number of nations for which data cannot at present be accessed. Anonymized CIS-4 microdata can be accessed for only 15 of the EU-27, and nonanonymised data can be accessed at Eurostat's Safe centre in Luxumbourg for only 21 of the EU-27. Further, access to non-anonymised data depends on gaining authorisation of use from the nations concerned. See http://epp.eurostat.ec.europa.eu/portal/page/portal/microdata/cis
} 
22.4 percent of the total sample. The bar chart below shows the percentage of firms that are innovative according to this definition for the 27 member nations.

Figure 2

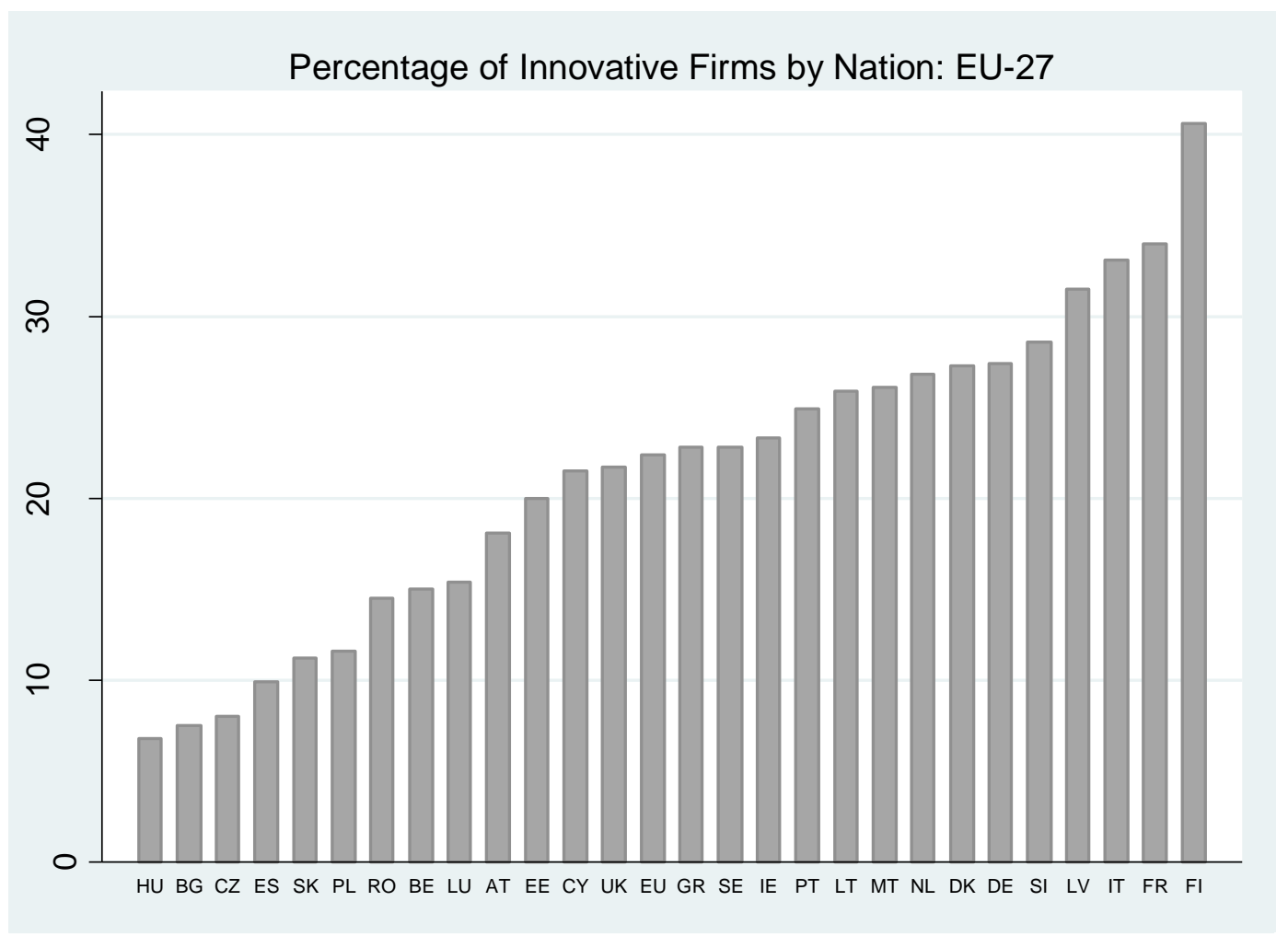

While the criteria used clearly identify firms that have demonstrated an in-house capacity for innovation, it is important to keep in mind certain limitations of the measure. The Innobarometer survey does not include questions that would allow one to capture the importance or wider impact of innovations. In particular, the survey does not provide the basis for distinguishing between minor innovations that are marketed solely on the local market, and innovations that have wider impacts and are marketed on highly competitive international markets. This helps to account for certain of the results that may appear surprising, such as the fact that the proportions of firms classified as innovators in Latvia, Slovenia are well above the EU average or that the performance of Malta Lithuania and Portugal are somewhat higher than that of Sweden or the UK.

The independent enterprise-level variables include a five-level categorical variable for the sector of activity (SCTR), a four-level categorical variable for firm size (SIZE) and a binary 
variable (GRWTH) equal to 1 if the enterprise's annual income growth was greater than 10 percent between 2004 and 2006. Table 4 presents the frequencies of the level-1 variables.

Table 3

Frequencies for the employee-level variables

\begin{tabular}{|c|c|c|c|c|c|}
\hline $\begin{array}{l}\text { Annual income } \\
\text { growth 2004-2006 }\end{array}$ & & & & & \\
\hline Increase $>10 \%$ & Total & & & & \\
\hline 1,787 & 5,036 & & & & \\
\hline \multicolumn{6}{|l|}{$\overline{\text { Size }}$} \\
\hline 20-49 employees & $50-249$ & $250-499$ & $>499$ & Total & \\
\hline 1,860 & 2,049 & 519 & 608 & 5,036 & \\
\hline \multicolumn{6}{|l|}{ Sector } \\
\hline $\begin{array}{l}\text { Manufacturing and } \\
\text { Mining }\end{array}$ & $\begin{array}{l}\text { Construction } \\
\text { and utilities }\end{array}$ & $\begin{array}{l}\text { Retail and } \\
\text { other services }\end{array}$ & $\begin{array}{l}\text { Business and } \\
\text { financial }\end{array}$ & Other & Total \\
\hline 2,025 & 566 & 1535 & 811 & 99 & 5,036 \\
\hline
\end{tabular}

\subsection{The multi-level logit model}

Before presenting the results of the econmetric analysis, I briefly compare the structure of the two-level random intercept logit model used here to that of the standard single-level logit model. ${ }^{16}$ The single-level logit model takes the following form. Let $y_{i}$ indicate the binary reponse $(0,1)$ for the ith unit and let $\pi_{i}$ be the probability that $y_{i}=1$

The logit link function has the form

$\operatorname{logit}\left(\pi_{i}\right)=\log \left(\pi_{i} / 1-\pi_{i}\right)=\beta_{0}+\beta_{1} x$

where the quantity $\left(\pi_{i} / 1-\pi_{i}\right)$ is the odds that $y_{i}=1$

\footnotetext{
${ }^{16}$ For a detailed presentation of multi-level models with dichotomous or binary responses, see Rabash (2005) and Goldstein (2003).
} 
The use of a two-level model is signaled by presence of subscripts $i$ and $j$ with the subscripts $j$ varying across the level 2 units and the subscripts $i$ varying from individual to individual within the level 2 units. Unlike the single-level logit model, in the two-level random intercept model the intercept term consists of two terms: a fixed component $\beta_{0}$ and a random effect $\mathbf{u}_{0 j}$ due to the fact that the level 2 units are treated as a random sample from a population of units.

$\operatorname{logit}\left(\pi_{i j}\right)==\beta_{0 \mathrm{j}}+\beta_{1} x_{i j}$

$\beta_{0 j}=\beta_{0}+\mathrm{u}_{0 j}$

The random effect $\mathbf{u}_{0 j}$ measures the departure of the $\mathrm{jth}$ unit's intercept from the average or summary intercept across all level 2 units predicted by the fixed parameter, $\beta_{0}$. It is assumed that $\mathrm{u}_{0 j}$ follows a normal distribution with mean zero and variance $=\sigma_{u 0}^{2}$

Level-2 context variables $x_{2 j}$ can be included in order to estimate the fixed effects of differences in context conditions on the dependent variable. Such direct effects modify the intercept and reduce the variabilty in the intercept across level- 2 units $\left(\mathrm{u}_{0_{j}}\right)$.

$\operatorname{logit}\left(\pi_{i}\right)=\beta_{0 j}+\beta_{1} \mathrm{x}_{1 i j}+\beta_{2} x_{2 j}$

$\beta_{0 \mathrm{j}}=\beta_{0}+\mathrm{u}_{0 j}$

The objective here is to predict the likelihood of an enterprise being innovative in terms of factors operating at two levels, the enterprise level and the national level. The structure of the full model that is estimated, including the national-level fixed effects, is given in equation (4). The subscripts $j$ vary across the sample of 27 EU nations and the subscrits $i$ vary from enterprise to enterprise within nations.

$\operatorname{logit}\left(\pi_{i}\right)=\beta_{0 j}+\beta_{1} \mathrm{SCTR}_{i j}+\beta_{2} \mathrm{SCTR}_{i j}+\beta_{3} \mathrm{SCTR}_{i j}+\beta_{4} \mathrm{SCTR}_{i j}+\beta_{5} \mathrm{SIZE} 2_{i j}+$ $\beta_{6} \mathrm{SIZE}_{i j}+\beta_{7} \mathrm{SIZE}_{i j}+\beta_{8} \mathrm{GRWTH} 1_{i j}+\beta_{9} \mathrm{GRWTH} 2_{i j}+\beta_{10} \mathrm{FACTOR}_{j}+\beta_{11} \mathrm{FACTOR}_{j}$

with

$\beta_{0 \mathrm{j}=} \beta_{0}+\mathrm{u}_{0 j}$ 
Since the enterprise-level variables are all binary 0,1 variables and the two factors measuring differences in national-level context conditions have means equal to 0 , the log-odds of innovation for the reference enterprise in the 'average' nation will be the fixed parameter $\beta_{0}$ plus the associated random effect $\mathrm{u}_{0 j}$. In nations where the values for the context variables are above (below) average, the fixed component of the predicted log-odds of innovation for the reference enterprise will be higher (lower) than $\beta_{0}$ depending on whether the coefficients on the national context variables are positive or negative. For example, if the estimated coefficient on FACTOR1 measuring the importance of flexicurity is positive then, other context conditions being equal, in nations with higher levels of flexicurity the fixed component of the predicted log-odds of innovation for the reference enterprise will be greater than $\beta_{0}$. Including the effects of the context variables on the dependent variable should reduce the estimated variance in the intercept term across nations $\left(\sigma_{u 0}^{2}\right)$.

Table 4 presents the results for the random intercept model without country-level fixed effects. Focusing on the level-1 fixe effects, the results show that relative to construction and utilities enterprises in the other four sectors are more likely to innovate with the positive effect being the largest in the manufacturing and mining sector. Enterprises in the 20-49 employee range are less likely to innovate than larger enterprise and the results point to a positive impact of increases in enterprise size on the likelihood of innovating. There is a small and statistically significant positive impact of higher rates of prior income growth on the likelihood of innovating.

The random intercept estimate of .32 points to sizeable variance in the level of innovative activity across the 27 member nations after having controlled for the enterprise-level characteristics. The LR test reported at the bottom of the table tests the null hypothesis that the proportion of the total residual variance accounted for by differences between nations is 0 . This is rejected at the .000 level. 
Table 4

Multi-level logistic regressions

\begin{tabular}{|c|c|}
\hline & Model 1 \\
\hline \multicolumn{2}{|l|}{ Enterprise-level fixed effects } \\
\hline Intercept & $-2.45 * * *$ \\
\hline Manufacturing & $1.27 * * *$ \\
\hline Construction, utilities & Reference \\
\hline Retail and other services & $.33^{* *}$ \\
\hline Business and financial services & $.83 * * *$ \\
\hline Other & $.55^{* *}$ \\
\hline $20-49$ employees & Reference \\
\hline $50-249$ employees & $.41 * * *$ \\
\hline 250 - 499 employees & $.94 * * *$ \\
\hline & $1.13^{* * *}$ \\
\hline $\begin{array}{l}\text { Increase in income > 10\% } \\
\text { between } 2004 \text { and } 2006\end{array}$ & $.30 * * *$ \\
\hline $\begin{array}{l}\text { Random effects } \\
\text { Intercept }\end{array}$ & $.32(.10)$ \\
\hline LR vs. logistic regression & $\begin{array}{l}\text { Chibar } 2(01)=191.00 \\
\text { Prob }>=\text { chibar2 }=0.000\end{array}$ \\
\hline
\end{tabular}

Figure 3, on the basis of the random intercept regression results, presents a bar chart showing the modal estimates of the random intercepts with 95 percent confidence intervals for the 27 EU member nations. These are estimates of how much the intercept in each nation departs from the overall average for the population of 27 nations and thus provide a measure of the importance of 'national effects' on the level of innovation activity. It is clear from the large size of the confidence intervals that the rankings are not precise and it would perhaps be best to refer to a coarser distinction between below, average and above average nations. 
Figure 3

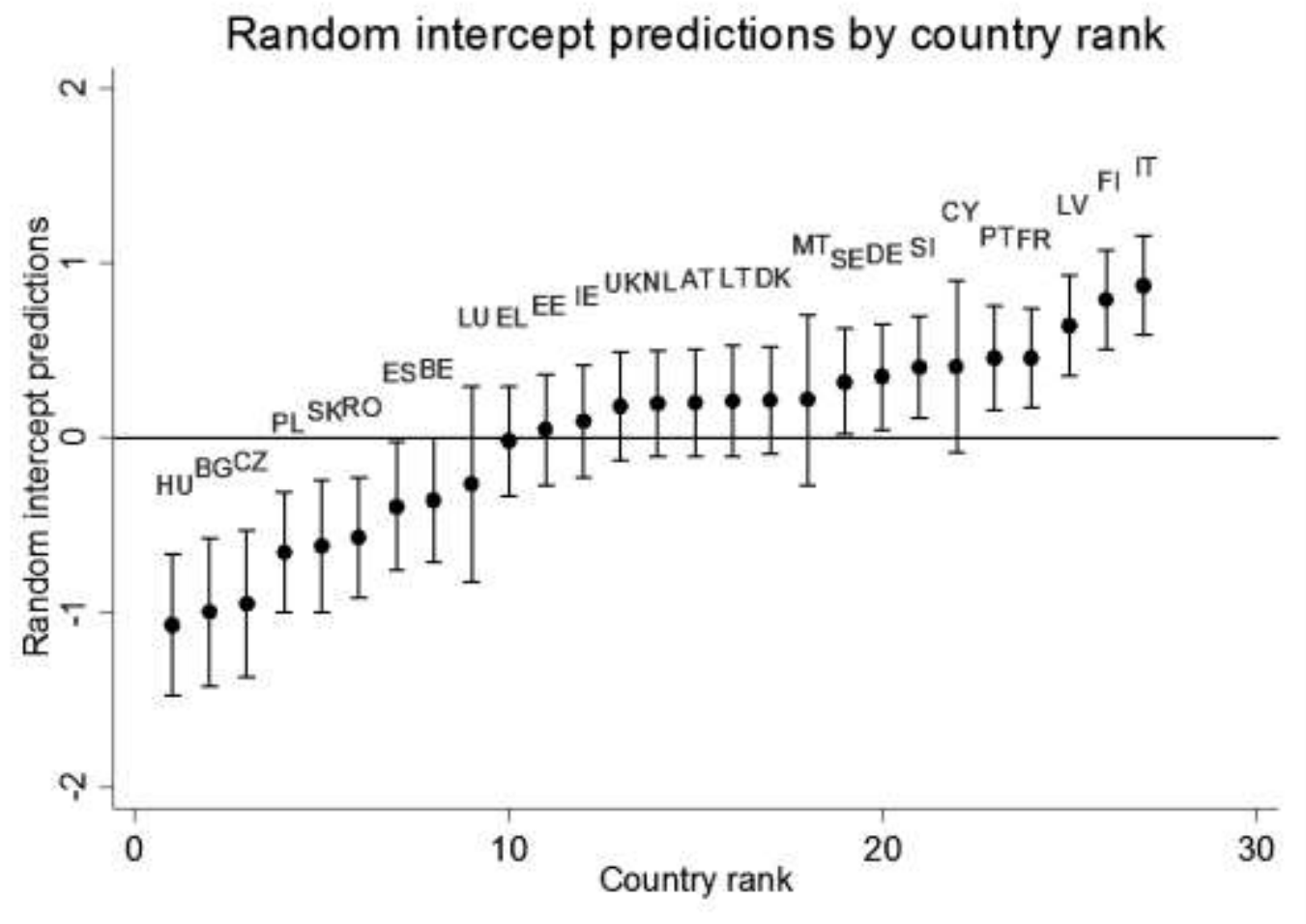

The results show that amongst the EU-15 there is an above average national-level effect on innovation in Italy, Finland, Sweden, Germany, Portugal, and France. The effect is above average in only two of the new member countries nations: Latvia and Slovenia. There is a below average national effect in Spain, Belgium and in a number of the new member nations including Bulgaria, Hungary, the Czech Republic, Slovakia, Romania and Poland. The effect is not statistically different from the average in Luxembourg, Estonia, Lithuania, Greece, Malta, Denmark, the Netherlands, Ireland, Austria, the UK and Cyprus. The ranking of countries in Figure 3 is similar but not identical with the ranking shown in the descriptive statistics in Figure 2. This can be explained by the fact that the random intercept predictions take into account differences in the size structure of firms and in industrial structure across nations. Moreover the random intercept predictions make it clear that in many cases the apparently above average national innovation performance suggested by the descriptive statistics in Figure 2 are not statistically significant.

Table 5 presents the random intercept model with country-level fixed effects in order to develop estimates of the impact of national labour market and education and training systems 
on the likelihood of an enterprise innovating. Including the national level fixed effects should help account for some of the variance in intercept term across nations.

Table 5

Multi-level logistic regression with contextual effects

\begin{tabular}{|c|c|}
\hline & Model 2 \\
\hline \multicolumn{2}{|l|}{ Enterprise-level fixed effects } \\
\hline Intercept & $-2.45 * * *$ \\
\hline Manufacturing & $1.28 * * *$ \\
\hline Construction, utilities & Reference \\
\hline Retail and other services & $.33^{* *}$ \\
\hline Business and financial services & $.83^{* * *}$ \\
\hline Other & $.56 * *$ \\
\hline $20-49$ employees & Reference \\
\hline $50-249$ employees & $.41 * * *$ \\
\hline 250 - 499 employees & $.94 * * *$ \\
\hline >499 employees & $1.13^{* * *}$ \\
\hline $\begin{array}{l}\text { Increase in annual income }>10 \\
\text { percent }\end{array}$ & $.30 * * *$ \\
\hline \multicolumn{2}{|l|}{ Country-level fixed effects } \\
\hline Factor1 (flexicurity) & $.28 * * *$ \\
\hline $\begin{array}{l}\text { Factor2 (continuing vocational } \\
\text { training) }\end{array}$ & -.03 \\
\hline $\begin{array}{l}\text { Random effects } \\
\text { Intercept }\end{array}$ & $.24(.08)$ \\
\hline LR test v. logistic regression & $\begin{array}{c}\text { Chibar2 }(01)=141.62 \\
\text { Prob }>=0.000\end{array}$ \\
\hline
\end{tabular}

*** significant at .01 level; **.05 level; * .10 level

There are no significant changes in the coefficients on the level-1 variables. The random intercept estimate is reduced to .24 indicating that the inclusion of two level- 2 context variables has accounted for about a quarter of the variance in the intercept between nations. A major result is that there is a positive and significant impact of the aggregate measure of flexicurity on the likelihood of innovating. Since the means of the underlying factors are 0 and their standard deviations are equal to1, the results show that a one standard deviation 
increase in a nation's score on the flexicurity scale results in a .28 expected increase in the $\log$ odds of innovating. Expressed in terms of odds, a one standard deviation increase along the flexicurity scale results in an approximately 32 percent increase in the odds of innovating. This result provides strong support for the hypothesis developed in the paper that the combination of flexible labour markets, generous systems of unemployment including the use of active labour market policies, and well developed systems of life-long learning are associated with higher levels of national innovation performance.

The results also show a very weak negative and non-statistically significant effect of greater development of systems of continuous vocational training on the likelihood of innovating. This result suggests that placing a strong emphasis on the development of systems of further vocational training independently of investments in other complementary institutional arrangements constitutes an insufficient basis for improving national innovative performance.

\section{Conclusion}

This paper began with some general reflections on the relation between labour market flexibility, skills and innovative performance. The argument was made that highly innovative firms need to balance the use of labour turnover in order to bring in new knowledge with policies that serve to preserve the largely tacit industry-specific problem solving capabilities that employees acquire through their practical work activity. A case was made for the way the organisation of firms into industry clusters promotes to the development of localised networks and professional and social relationships that contribute to the efficient accumulation and transfer of tacit knowledge in an inter-firm career framework. Further, it was argued that such localised networks and professional relationships are more likely to develop in national systems with well developed systems of flexicurtity.

In order to provide empirical support for this hypothesis, multi-level logistic regression analysis was used to explore simultaneously the impact of enterprise-level variables and measures of national labour market and education and training systems on the likelihood of a firm innovating. The results support the view that firms are more likely to innovate in national institutional settings characterised by the combination of flexible labour markets, generous systems of unemployment protection including the use of active labour market policies, and well-developed systems of life-long learning. 
While the relevance of the analysis for EU-policy can only be alluded to here, the results provide support for key elements of the EU 2020 strategy. In particular, they point to important synergies between the objective of improving the innovative performance of European enterprises and central aspects of the European Employment Strategy, including expanding and improving investments in human capital through the provision of efficient lifelong learning open to all, and promoting greater flexibility with security though the use of active labour market policies, policies to promote labour mobility and adequate systems of social security. Moreover, while an analysis based on cross-sectional data cannot address dynamic problems of institutional change, the comparison of EU member nations clearly suggests that flexicurity is not an all or nothing proposition and that nations rather can be characterised in terms of the degree to which they have put in place flexicurtiy regimes. This in turn provides support for an underlying premise of the European Employment Strategy that institutional change can be brought about progressively and that even incremental advances in the direction of desired policy goals can be to good effect.

\section{References}

Akkermans, D., C. Castaldi, and B. Los, 2009, 'Do 'liberal market economies' really innovate more radically than 'coordinated market economies'? Hall and Soskice reconsidered', 2009, Research Policy, 38, pp; 181-91.

Amable, B. 2003. The Diversity of Modern Capitalism, Oxford, Oxford University Press.

Angel, D. 2000. 'High-technology agglomeration and the labor market: the case of Silicon Valley', in M. Kenney (ed.) Understanding Silicon Valley: the anatomy of an entrepreneurial region, Stanford, Stanford University Press.

Almeida, P. and B. Kogut. 1999. 'Localisation of knowledgeand the mobility of engineers in regional networks' Management Science, Vol. 45, No. 7, pp. 905-17.

Arundel, A., Lorenz, E, Lundvall, B.-Å. and Valeyre, A. 2007. 'How Europe's economies learn: a comparison of work organization and innovation mode for the EU-15', Industrial and Corporate Change, vol. 16, no. 6, pp. 1175-1210. 
Boschma, R.A., Eriksson, R. and Lindgren, U., 2009. 'How does labour mobility affect the performance of plants? The importance of relatedness and geographical proximity', Journal of Economic Geography, vol. 9 (2), pp.169-190.

Bredgaard, T, F. Larsen and PK. Madsen, 2005. 'The Flexible Danish Labour Mazrket - a Review', CARMA, Aalborg University, Aalborg.

Breschi, S. and F. Lissoni, 2001. Knowledge Spillovers and Local Innovation Systems: A Critical Survey, 2001. Industrial and Corporate Change, 10/4 pp. 975-1005.

Camagni, R. (ed.), 1991. Innovation networks. Spatial perspectives. Bellhaven Press, London/New York.

Carnoy M, M. Castelss and C. Benner, 1997. Labour market and employment practises in the age of flexibility: A case of Silicon Valley. International Labour Review 136: 27-48.

Dent, R. and J. Wiseman, 2008. Continuing Vocational Training Survey (CVTS3), BMG Research, Department of Innovation, Universities and Skills, London.

Eamets, R. and J. Masso, 2005. 'The Paradox of the Baltic States: Labour Market Flexibility but Protected Workers?' European Journal of Industrial Relations, pp. 17190.

Gertler, M S. 2003.'Tacit knowledge and the economic geography of context, or the undefinable tacitness of being (there)' Journal of economic geography, 3, pp. 75-99.

Goldstein, H. 2003. Multilevel statistical models (3rd edition). London, Arnold.

Hall, P. and D. Soskice, 2001, Varieties of Capitalism, Oxford, Oxford University Press.

Holm, J. E. Lorenz, B-A. Lundvall and A. Valeyre, 2010. 'Organisational Learning and Systems of Labour Market Regulation in Europe', Industrial and Corporate Change.

Innobarometer 2007 Analytical Report, DG Enterprise and Industry, European Commission, 2008

Job Mobility in the European Union: optimizing its social and economic benefits, Danish Technological Institute, April 2008.

Klepper, S. 2007. 'Silicon Valley - A chip off the old Detroit Bloc', in D. Audretsch and R. Strom (eds.) Entrepreneurship and Public Policy, Cambridge, Cambridge University Press. 
Lam, A. and B.A. Lundvall, 2006. 'The Learning Organisation and National Systems of Competence Building and Innovation' in E. Lorenz and B.A. Lundvall (eds.) How Europe's Economies Learn: Coordinating competing models, Oxford: Oxford University Press.

Lorenz, E. and B-A. Lundvall, (eds.) 2006. How Europe's Economies Learn: Coordinating competing models, Oxford, Oxford University Press.

Lorenz, E. and B-A. Lundvall, 2010. "The organisation of work and systems of labour market regulation and social protection: a comparison of the EU-15", in M. Ekman, B.Asheim, B. Gustavsen and Ö. Pålshaugen, (eds.) Learning and regional innovation: Scandinavian models, Palgrave (Macmillan).

Lorenz, E. and B.A. Lundvall, 2011. "Accounting for Creativity in the European Union A multi-level analysis of individual competence, labour market structure, and systems of education and training" (forthcoming) Cambridge Journal of Economics.

Masden, P.K. ,2003. 'Flexicurity through Labour market policies and institutions in Denmark', in P. Auer and S. Cazes (ed.) Employment Stability in an age of Flexibility', ILO, Geneva.

Mintzberg, H. 1979. The Structuring of Organizations, Englewood cliffs.

Moore, G. and K. Davis, 2001. 'Learning the Silicon Valley Way', Working Paper, Stanford Institute for Economic Policy Research, Stanford University.

Nooteboom, B. 1999. Interfirm alliances: analysis and design, London, Routledge.

Nooteboom, B. 2000. Learning and Innovation in organisations and economies, Oxford, Oxford University Press.

Rasbash, J., F. Steele, W. Browne, and B. Prosser, 2005. A User's Guide to MLwiN, Centre for Multilevel Modelling, University of Bristol.

Rogers, E. and J. Larsen, Silicon Valley Fever: Growth of high technology culture, New York, Basic Books.

Romans, F. 'Population and Social Conditions', Data in Focus, 21/2007, Eurostat.

Saxenian, A. 1996. Beyond Boundaries: Open Labor Markets and Learning in Silicon Valley, Oxford, Oxford University Press. 
Taylor, M. 2004, 'Empirical evidence against Varieties of Capitalism's theory of technological innovation'; International Organization, 58, pp. 601-31.

Whitley. R. 2006. 'Innovation systems and institutional regimes: the construction of different types of national, sectoral and transnational innovation systems', in E. Lorenz and B-A. Lundvall (eds.) How Europe's Economies Learn: Coordinating competing models, Oxford: Oxford University Press. 